Article

\title{
Anti-Neuroblastoma Properties of a Recombinant Sunflower Lectin
}

\author{
Marcela Pinedo ${ }^{1, *}$, Melanie Genoula ${ }^{1}$, María Ximena Silveyra ${ }^{1}$, André De Oliveira Carvalho ${ }^{2}$, \\ Mariana Regente ${ }^{1}$, Marianela Del Río ${ }^{1}$, Júlia Ribeiro Soares ${ }^{2}$, Valdirene Moreira Gomes ${ }^{2}$ and \\ Laura De La Canal ${ }^{1}$ \\ 1 Instituto de Investigaciones Biológicas (IIB), Consejo Nacional de Investigaciones Científicas y \\ Técnicas (CONICET), Universidad Nacional de Mar del Plata, Funes 3250, 7600 Mar del Plata, Argentina; \\ mgenoula@gmail.com (M.G.); mxsilveyra@gmail.com (M.X.S.); mregente@mdp.edu.ar (M.R.); \\ maris03_5@hotmail.com (M.D.R.); ldelacan@mdp.edu.ar (L.D.L.C.) \\ 2 Laboratório de Fisiologia e Bioquímica de Microrganismos, Centro de Biociências e Biotecnologia, \\ Universidade Estadual do Norte Fluminense, Campos dos Goytacazes 28013-602, Brazil; \\ andre@uenf.br (A.D.O.C.); julliah@hotmail.com (J.R.S.); valmg@uenf.br (V.M.G.) \\ * Correspondence: mpinedo@mdp.edu.ar; Tel.: +54-223-475-3030 \\ Academic Editor: Els Van Damme \\ Received: 25 November 2016; Accepted: 20 December 2016; Published: 10 January 2017
}

\begin{abstract}
According to their sugar recognition specificity, plant lectins are proposed as bioactive proteins with potential in cancer treatment and diagnosis. Helja is a mannose-specific jacalin-like lectin from sunflower which was shown to inhibit the growth of certain fungi. Here, we report its recombinant expression in a prokaryotic system and its activity in neurobalstoma cells. Helja coding sequence was fused to the pET-32 EK/LIC, the enterokinase/Ligation-independent cloning vector and a $35 \mathrm{kDa}$ protein was obtained in Escherichia coli representing Helja coupled to thioredoxin (Trx). The identity of this protein was verified using anti-Helja antibodies. This chimera, named Trx-rHelja, was enriched in the soluble bacterial extracts and was purified using $\mathrm{Ni}^{+2}$-Sepharose and D-mannose-agarose chromatography. Trx-rHelja and the enterokinase-released recombinant Helja (rHelja) both displayed toxicity on human SH-SY5Y neuroblastomas. rHelja decreased the viability of these tumor cells by $75 \%$ according to the tetrazolium reduction assay, and microscopic analyses revealed that the cell morphology was disturbed. Thus, the stellate cells of the monolayer became spheroids and were isolated. Our results indicate that rHelja is a promising tool for the development of diagnostic or therapeutic methods for neuroblastoma cells, the most common solid tumors in childhood.
\end{abstract}

Keywords: agglutinin; Helianthus annuus; Helja; jacalin; neuroblastoma; recombinant lectin; tumor toxicity

\section{Introduction}

Lectins are proteins that specifically bind different sugar motifs due to their carbohydrate recognition domains [1]. This ability allows them to interact with glycoproteins and glycolipids, fulfilling diverse functions related to cell recognition [2,3]. As they can recognize the carbohydrate code on different cell surfaces, they might distinguish tissue types and the occurrence of variations in the exposed glycocode [4]. It must be taken into account that the malignant transformation of cells toward the invasive behavior leading to metastasis has been associated with complex alterations in the glycosylation process, which, in turn, can produce changes in cell-cell and cell-extracellular matrix (EM) interactions and favors the progression of the tumors [5,6]. Thus, the binding properties of the lectins allow their use in the diagnosis and treatment of cancer disease $[4,7,8]$, and it is not 
surprising that a range of biomedical applications has been described for different lectins $[1,8]$. In fact, a significant number of papers and patents use lectins as diagnostic tools [9].

Plant lectins have attracted special attention because of their abundance in seeds and ease of preparation. They have been shown to bind specifically to cancer cell membranes or receptors, causing inhibition of tumor growth $[4,10,11]$. In addition, their differential recognition of cells may also be viewed as an essential part of the mechanism required for the targeted delivery of drugs [12]. Some plant lectins also reap the benefit of antifungal and antiviral activities [13-15]. However, it was claimed that their range of applications needs to be improved with the availability of novel lectins with differential specificity and biological targets [8]. Nevertheless, it must be taken into account that the thorough analysis of the biological properties is necessary to exclude harmful consequences that may arise in vivo by the administration of lectin-containing extracts [16].

We have previously characterized Helja, a lectin isolated from sunflower seedlings which exhibits mannose specificity and belongs to the Jacalin family [17]. This lectin was shown to inhibit the growth of human pathogenic fungi [14]. However, the exploration of other putative activities was limited by the low abundance of Helja in its natural source. Hence, we decided to conduct its recombinant expression taking advantage of the absence of post-translational modifications in native Helja [18] that allowed the use of a bacterial platform.

The aim of this work was to produce an active recombinant form of the jacalin-like lectin Helja and test its effect on SH-SY5Y neuroblastoma cells. Neuroblastomas account for 15\% of cancer related deaths in children and represent the most common extracranial solid tumor during childhood [19]. The surface of these cells exhibit glycoproteins decorated with mannose residues [20-22] and might hence be a target of Helja that would allow the use of the lectin in diagnosis or therapy of neuroblastoma.

\section{Results and Discussion}

\subsection{Expression of the Recombinant Jacalin-Like Lectin Helja}

A problem frequently encountered during the production of recombinant proteins in E. coli is the occurrence of insoluble and/or non-functional forms of those proteins. To overcome this limitation, we decided to express Helja as a fusion protein with thioredoxin since it increases the solubility of heterologous proteins synthesized in E. coli cytoplasm [23]. Helja amino acid sequence was previously deduced by cloning and sequencing the complete coding sequence (CDS) [24]. Therefore, in this work, Helja CDS was cloned in the expression enterokinase/Ligation-independent cloning vector pET-32Ek/LIC to obtain a chimeric thioredoxin-Helja protein (Trx-rHelja) in the E. coli Rosetta-gami2 (DE3) pLysS expression strain. Subsequent vector sequencing confirmed that Helja CDS was in frame with the ORF of the vector containing the His-tag and the enterokinase cleavage site upstream the methionine 1 of Helja (Figure S1). In order to obtain the recombinant protein, isopropyl $\beta$-D-1-thiogalactopyranoside (IPTG) induced cells were lysed by sonication, and the protein extracts were compared with those of un-induced cultures using $12 \%$ denaturing polyacrylamide gel electrophoresis SDS-PAGE. Figure 1A shows the occurrence of a band of approximately $35 \mathrm{kDa}$ enriched in the $0.5 \mathrm{mM}$ IPTG treated cultures. This MW is in agreement with the fusion of Helja to thioredoxin (Trx) and the His tags plus the entorokinase recognition sequences present in the vector. To validate the identity of the induced protein, an immunoblot was done using antibodies raised against Helja purified from sunflower seedlings [17]. The band of $35 \mathrm{kDa}$, immunodetected in the membrane showed in Figure 1B, confirmed the occurrence of the jacalin-like lectin, now on named Trx-rHelja. This result supports the fact that the recombinant protein was induced and translated in the correct frame in the prokaryotic expression system.

The expression conditions were further optimized to increase Trx-rHelja production and solubility. The induction with $0.5 \mathrm{mM}$ IPTG with a growing temperature of $30^{\circ} \mathrm{C}$ was found to be the best mode to produce the soluble recombinant protein. Under these conditions, the $35 \mathrm{kDa}$ induced protein was 
enriched in the 10,000 g soluble fraction (SN) when it was compared to the pellet (PP) obtained from E. coli extracts (Figure S2). Therefore, it was concluded that the overall process of Trx-rHelja production was successful.

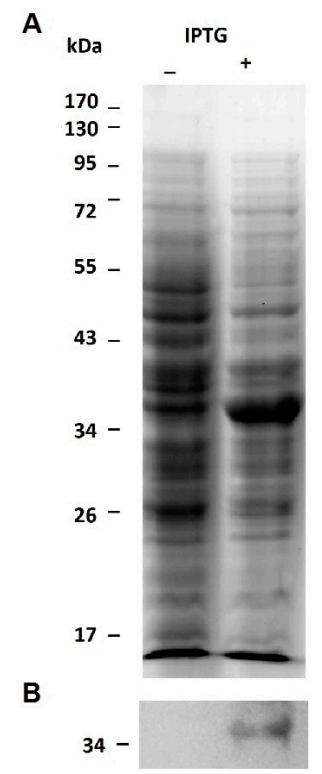

Figure 1. Induction of recombinant Trx-rHelja expression. The protein profile of extracts was obtained after lysis of cells from un-induced (-) or isopropyl $\beta$-D-1-thiogalactopyranoside (IPTG) induced (+) E. coli cultures. The extracts obtained from $0.1 \mathrm{~mL}$ of cell cultures with an OD at $600 \mathrm{~nm}$ of 1.5 were loaded on a $12 \%$ denaturing polyacrylamide gel electrophoresis, SDS-PAGE, and subsequently stained with Coomassie Brillant Blue (A). Immunodetection of Trx-rHelja in extracts of $0.01 \mathrm{~mL}$ of un-induced (-) or IPTG induced (+) cell cultures. Gel performed as described above was transferred to nitrocellulose, blocked and incubated sequentially with 1:3000 anti-Helja polyclonal antibodies and alkaline phosphatase-conjugated anti-rabbit IgG 1:10,000 (B). Figures are representative of three $(n=3)$ independent experiments. Molecular mass markers are indicated on the left.

\subsection{Purification of the Recombinant Helja}

The presence of six histidine residues linking the thioredoxin and the lectin domains allowed the isolation of Trx-rHelja using a metal affinity chromatography. Thus, the SN fraction of induced cultures was loaded on $\mathrm{Ni}^{2+}$-Sepharose matrix and the retained $(\mathrm{R})$ proteins were eluted with $150 \mathrm{mM}$ imidazole. Both the non-retained (NR) and the R fractions recovered from the matrix were analyzed by SDS-PAGE. The $\mathrm{R}$ fraction was enriched in a protein band of the expected molecular mass for Trx-rHelja (Figure 2). Since other proteins were also evident in this fraction, an affinity chromatography with D-mannose attached to agarose resin was used to further purify Trx-rHelja. The SDS-PAGE analysis clearly demonstrated that the recombinant protein was bounded to the matrix and eluted with mannose (Figure 2). Therefore, this procedure not only was useful for the purification of the recombinant protein but also showed that Trx-rHelja appears to have a sugar-binding capability similar to the native Helja even if it is still fused to the Trx and His tags. It also indicates that the lectin was correctly folded in the cytoplasm of E. coli, as the mannose binding activity depends on the conformation properties.

Other lectins successfully expressed in bacteria include the lectins from the blue-green algae Microcystis viridis called MVL [25], the jacalin lectin CRLL from leaves of Cycas revoluta [26] and frutalin from Artocarpus incised [27]. However, when E. coli was used to produce the recombinat jacalin from Artocarpus intergrifolia, the obtained chimera had reduced carbohydrate binding affinity compared to the native form. The authors justified this later result on the necessity of the posttranslational processing required for the protein [28]. 


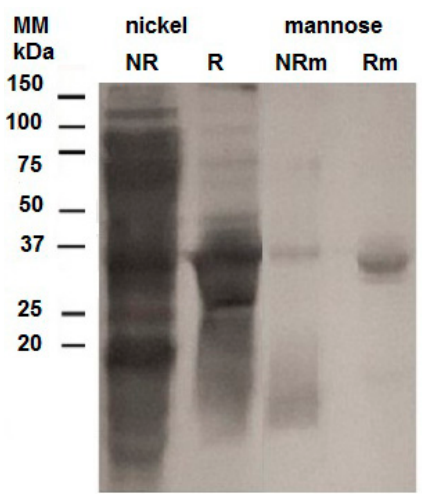

Figure 2. Recombinant Trx-rHelja purification by affinity chromatography. The protein profile of samples collected during Trx-rHelja purification scheme was analyzed using sequentially affinity for $\mathrm{Ni}^{2+}$-Sepharose and mannose-agarose matrixes. The soluble fraction (SN) of extracts from $100 \mathrm{~mL}$ IPTG induced E. coli cultures were loaded on the metal affinity matrix and the non-retained (NR) or the retained $(\mathrm{R})$ fractions were recovered. Then, $\mathrm{R}$ was loaded on a mannose-agarose column and the proteins, the non-retained (NRm), and retained peaks ( $\mathrm{Rm}$ ) were recovered. Aliquots of $\mathrm{R}, \mathrm{NR}, \mathrm{Rm}$ and $\mathrm{NRm}$ fractions were analyzed in 12\% SDS-PAGE and subsequently stained with Coomassie Brillant Blue. Figure is representative of two $(n=2)$ independent experiments. Molecular mass markers are indicated on the left.

The release of Helja from the fused tags was performed through the incubation with enterokinase and the products of this reaction were evaluated in gels. Thus, the immunoblot assay of Figure $3 \mathrm{~A}$ shows that the enzyme significantly reduced the $35 \mathrm{kDa}$ band, representing the recombinant protein, and gave rise to a protein of around $20 \mathrm{kDa}$, the expected size for Helja. The immunoreactivity of the $20 \mathrm{kDa}$ band supports the fact that it was the desired recombinant jacalin like lectin, now on named rHelja. rHelja was isolated by loading the reaction mix on the $\mathrm{Ni}^{2+}$-affinity column (Figure 3B,C) and, in accordance with the absence of the histidine tag, it was recovered in the washing buffer. Finally, this fraction containing rHelja was exhaustively dialyzed against PBS and subsequently concentrated to test its bioactivity.

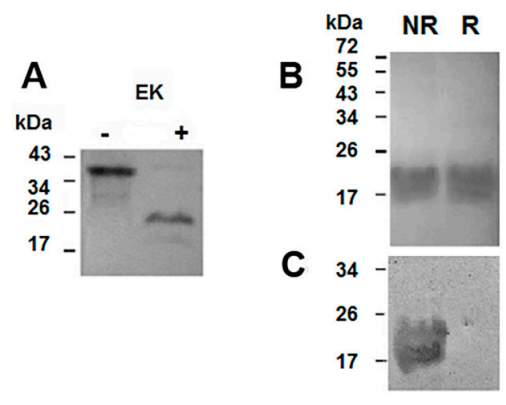

Figure 3. Trx-rHelja digestion with enterokinase and rHelja purification. Aliquots of the mix containing enterokinase after $(+)$ and before ( - ) of the incubation were loaded on $12 \%$ SDS-PAGE and subsequently transferred to nitrocellulose, blocked and incubated sequentially with 1:3000 anti Helja polyclonal antibodies and 1:10,000 alkaline phosphatase-conjugated anti-rabbit IgG (A). Aliquots of the proteins from the non-retained (NR) or the retained (R) peaks obtained after loading the products of the enterokinase digestion on the $\mathrm{Ni}^{2+}$-Sepharose matrix were analysed in a $12 \%$ SDS-PAGE and stained with Coomassie Brillant Blue (B) or transferred to nitrocellulose, blocked and incubated sequentially with 1:3000 anti Helja polyclonal antibodies and 1:10,000 alkaline phosphatase-conjugated anti-rabbit $\operatorname{IgG}(\mathbf{C})$. Figures are representative of three $(n=3)$ independent experiments. Molecular mass markers are indicated on the left. 


\subsection{Helja Activity on Human Neuroblastomas}

Trx-rHelja and the enterokinase-released rHelja were assessed for their effect on human neuroblastoma SH-SY5Y tumor cells using confluent cultures incubated for $24 \mathrm{~h}$ with 6 and $12 \mu \mathrm{M}$ of both lectins. After incubation, the cells were analyzed for their viability through an 3-(4,5-dimethylthiazol-2-yl)-2,5-diphenyltetrazolium bromide (MTT) standard assay. Viable cells reduce MTT to a purple formazan that can be quantified by a spectrophotometric approach. The diminution of the formazan concentration observed in the lectin treated cells relative to the controls clearly supports the cytotoxic action of the lectin on the SH-SY5Y cell line (Figure 4). The incubations with 6 and $12 \mu \mathrm{M}$ of the recombinant Trx-rHelja decreased cell viability to approximately $75 \%$ and $55 \%$, respectively, and rHelja also showed a dose-dependent diminution of cell viability. Only $25 \%$ of cells remained alive upon incubation with the highest rHelja concentration $(12 \mu \mathrm{M}$ or $200 \mu \mathrm{g} / \mathrm{mL})$.

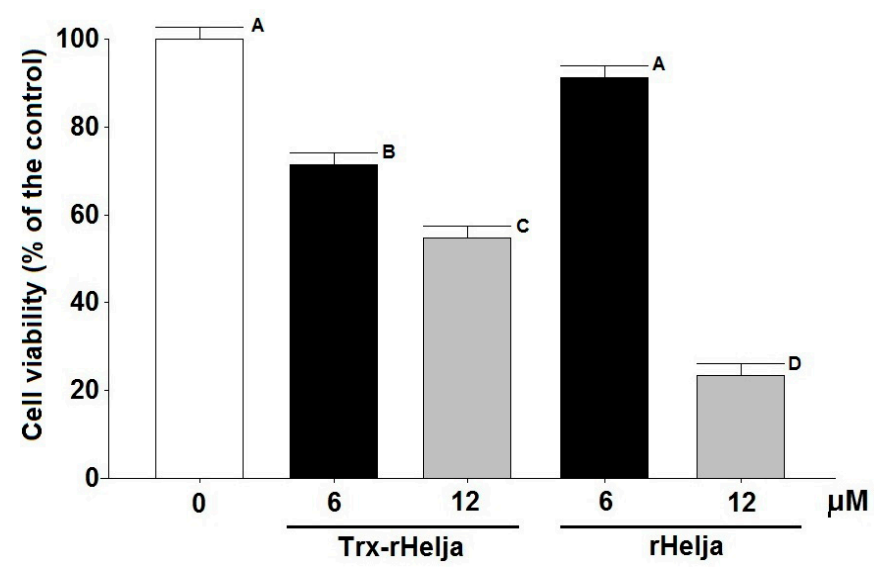

Figure 4. Cell viability of human SH-SY5Y neuroblastoma cells treated with Trx-rHelja or rHelja. The cells at density of $5 \times 10^{4}$ cell/well were grown for $24 \mathrm{~h}$ before the incubation with 6 and $12 \mu \mathrm{M}$ Trx-rHelja or rHelja. After an additional $24 \mathrm{~h}$, MTT reagent was added to the wells. Dimethyl sulfoxide was used to dissolve the formazan complex and the absorbance was measured at $570 \mathrm{~nm}$. The cellular viability was expressed as a percentage of the value obtained in the absence of treatment. Each experiment was tested in triplicates and they were repeated at least three times. Standard deviation, one-way ANOVA and Tukey test analysis $(p \leq 0.05)$ were performed using InfoStat software (2014, Agricultural College of the National University of Córdoba, Córdoba, Argentine). Different capital letters indicate significant differences.

The toxicity observed for rHelja is similar to the native and recombinant forms of frutalin, which is a $\alpha$-D-galactose specific jacalin able to affect HeLa cells with an $\mathrm{IC}_{50}$ of $100 \mu \mathrm{g} / \mathrm{mL}$ [29]. Similarly, the antitumoral activity for a lectin isolated from Del Monte banana, inhibited a $40 \%-60 \%$ the proliferation of leukemia cancer cells L1210 at concentrations among 80-500 $\mathrm{gg} / \mathrm{mL}$ [30].

Plant lectins with antitumoral activity have been recently reviewed [4,7] and a few of them have reached clinical trials. Bioactive molecules with potential as anticancer molecules include the Polygonatum odoratum lectin (POL) and concanavalin A (Con A). POL is a D-mannose specific protein of the B-lectin family with 50\% inhibitory rate on fibrosarcoma cells at 23-25 $\mu \mathrm{g} / \mathrm{mL}$ [8]. Meanwhile, Con A produces $60 \%-90 \%$ inhibition of human melanoma A375 cells when tested at $80 \mu \mathrm{g} / \mathrm{mL}$ [10]. The demonstration of Helja cytotoxicity on neuroblastoma cells shown in this report acquires a particular interest since, according to recent reviews and bibliographic searches, plant lectins reported to be active against neuroblastoma are scarce $[4,7,8,31]$. Here, we show that Trx-rHelja as well as rHelja induce the loss of the viability of neuroblastoma cells and support the idea that different versions of Helja are functional, even with the added tags, which might facilitate future applications.

The observation of neuroblatomas by optical microscopy provided more insight concerning rHelja action. Figure 5 shows significant morphological changes of the cells upon treatment. At the highest 
concentration tested $(12 \mu \mathrm{M})$, neuroblastoma cells exhibited a retraction of their neurite extensions. The cells acquired a typical apoptotic appearance. They changed from a monolayer of stellate adherent cells to isolated spheroid shaped cells, of smaller size and without the neuritis connections [32]. Taking into account the important role that carbohydrates bound to proteins and lipids of the cell surface in cell-cell interactions and adhesion with the EM play $[33,34]$, it can be hypothesized that Helja could disrupt the EM through interaction with cell surface sugar residues, thereby affecting the network of cells and their morphology. Indeed, CD24 and different isoforms of NCAM (NCAM-140 and NCAM-180), which are glycoproteins decorated with mannose residues that occur on the surface of neuroblastoma cells and are reported to be involved in cell adhesion [20,21].

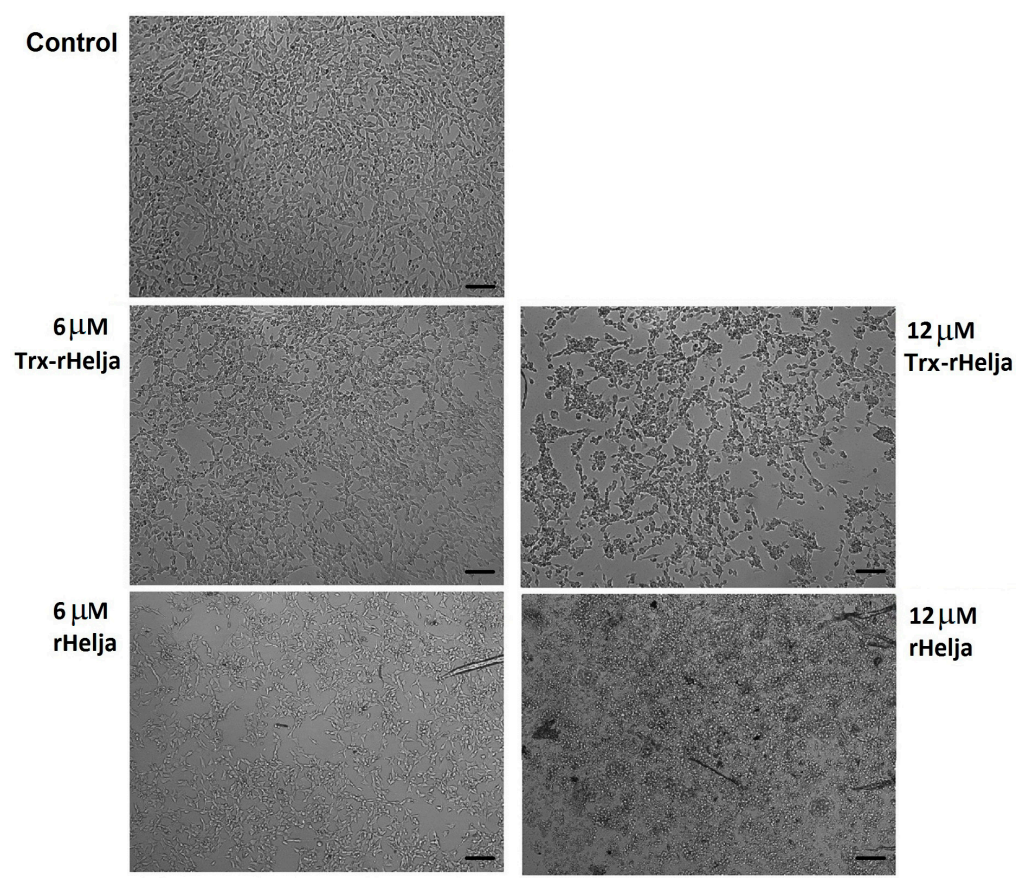

Figure 5. Cell morphology changes in human neuroblastoma SH-SY5Y cells treated with Trx-rHelja or rHelja. The cells at density of $5 \times 10^{4}$ cell/well were grown for $24 \mathrm{~h}$ before the incubation with 6 and $12 \mu \mathrm{M}$ Trx-rHelja or rHelja for additional $24 \mathrm{~h}$. Cells were examined using a phase contrast microscopy $(10 \times$ lens $)$. Scale bar $=10 \mu \mathrm{m}$.

Plant lectins can induce cytotoxicity, apoptosis and necrosis in various tumor cells using different mechanisms [11,35-37]. Some trigger apoptosis through the induction of specific caspases [11,38], while others, such as the mannose-binding lectins from Canavalia ensiformis (ConA) and Canavalia brasiliensis (ConBr), are able to make it through depolarization and permeabilization of mitochondrial membranes and accumulation of reactive oxygen species (ROS) [39]. Even though the basis of the cytotoxic activity of rHelja is not addressed in this work, it is tempting to speculate that oxidative stress could mediate neuroblastoma cell death since we have previously demonstrated that Helja induces ROS accumulation in other cells [14].

It has been recognized that it is imperative to conduct lectin research to identify which proteins have the greatest prospects against malignant cell lines threatening human health [8]. The results obtained in this study allowed us to exceed the limits imposed by the reduced availability of Helja in sunflowers. Expression in a prokaryotic system generated quickly and at low cost the soluble and active Trx-rHelja protein that, in turn, makes possible the production of rHelja. Both the fusion protein and rHelja are bioactive lectins cytotoxic against neuroblastoma. Therefore, Helja emerges as an alternative molecule with potential to be used as anticancer drug or in diagnosis, where the biopsy of tissues is an absolute requirement. 


\section{Material and Methods}

\subsection{Biological Material}

Chemically competent cells of Escherichia coli bacterial strain NovaBlue with relevant genotype: endA1 hsdR17 $\left(\mathrm{r}_{\mathrm{K} 12}{ }^{-} \mathrm{m}_{\mathrm{K} 12}{ }^{+}\right)$supE44 thi-1 recA1 gyrA96 relA1 lac $\mathrm{F}^{\prime}\left(\right.$ proA $^{+} B^{+}$lacl $\left.{ }^{q} \mathrm{Z} \Delta M 15:: \operatorname{Tn} 10\right)$ $\left(\mathrm{Tet}^{\mathrm{R}}\right)$ were used for general cloning and cells of Rosetta-gami2 $\left(\mathrm{DE}_{3}\right)$ pLysS with relevant genotype: $\Delta$ (ara-leu)7697 $\Delta$ lacX74 $\Delta$ phoAPvuIIphoRaraD139ahpCgalEgalKrpsL $\left(\mathrm{DE}_{3}\right) \mathrm{F}^{\prime}\left[\right.$ lac $^{+}$lacI ${ }^{\mathrm{q}}$ pro] gor522::Tn10trxB pLysSRARE23 $\left.\left(\mathrm{Cam}^{\mathrm{R}}, \mathrm{Str}^{\mathrm{R}}, \mathrm{Tet}^{\mathrm{R}}\right)^{4}\right)$ for the expression of the sequence fused in the pET-32 EK/LIC, the enterokinase/Ligation-independent cloning vector (cloning kit, Novagen, Applied Biosystems, Foster City, CA, USA).

Human neuroblastoma cell line SH-SY5Y ATCC ${ }^{\circledR}$ Catalog No. CRL-2266 ${ }^{\mathrm{TM}}$ was kindly provided by Dr. Tomás Falzone (Instituto de Biología Celular y Neurociencia "Prof. E. de Robertis", Buenos Aires).

\subsection{Construction of the Recombinant Expression Vector}

The set of specific primers for amplification of the Helja coding sequence intended to directionally clone the sequence in the pET-32 EK/LIC vector was designed according to the vector instruction manual (pET System Manual, Novagen). The complete coding sequence of Helja was previously obtained, GenBank KJ681498 [24]. The forward primer was 5'-GACGACGACAAG ATGGCTAACAACTACGTTGAGG-3' and the reverse was $5^{\prime}$-GAGGAGAAGCCCGGTCTAGGGA CTAAGTACGA-3' ${ }^{\prime}$. Underlined letters correspond to the sequence that anneals with the pET-32 EK/LIC vector and the italic letters to the sequence that anneals with Helja cDNA. Primers were synthesized by Invitrogen (Carlsbad, CA, USA).

Fragment amplifications were performed by PCR containing $1 \times$ Taq buffer with $\left(\mathrm{NH}_{4}\right)_{2} \mathrm{SO}_{4}$ (Fermentas), $1.5 \mathrm{mM} \mathrm{MgCl} 2,0.2 \mathrm{mM}$ dNTP, $1 \mu \mathrm{M}$ forward primer, $1 \mu \mathrm{M}$ reverse primer, $0.2 \mu \mathrm{L}$ cDNA obtained from sunflower cotyledons and 1.25 units Taq DNA polymerase I in a volume of $20 \mu \mathrm{L}$. The program used for amplification was $95^{\circ} \mathrm{C}$ for $3 \mathrm{~min}$, followed by 1 cycle of $95^{\circ} \mathrm{C}$ for $45 \mathrm{~s} ; 58^{\circ} \mathrm{C}$ for $45 \mathrm{~s}$ and $72{ }^{\circ} \mathrm{C}$ for $1.5 \mathrm{~min}$ and 35 cycles of $95{ }^{\circ} \mathrm{C}$ for $45 \mathrm{~s} ; 68^{\circ} \mathrm{C}$ for $45 \mathrm{~s}$ and $72{ }^{\circ} \mathrm{C}$ for $1.5 \mathrm{~min}$ (Verit Thermal Cycle, Applied Biosystems, Foster City, CA, USA). The PCR product was purified using the Wizard SV gel (Promega, Madison, WI, USA) and PCR clean up system (A9281 Promega, Madison, WI, USA) and treated with T4 DNA polymerase to generate the compatible overhang ends to be annealed the pET-32 EK/LIC. The pET-32 EK/LIC vector containing Helja cDNA sequence was named pET-Helja and was used for bacterial transformation.

\subsection{Transformation, Positive Colony Screening and Sequencing}

NovaBlue competent cells, transformed with pET-Helja were grown in liquid Luria-Bertani (LB) medium. A colony screening was done by plasmid extraction (isolated using Highway ADN PuriPrep kit from INBIO, Buenos Aires, Argentina). It was followed by a restriction analysis with $B g l \mathrm{II}$ and Eco RI as described in pET System Manual 11th Edition (Applied Biosystems, Foster City, CA, USA). Plasmids recovered from positive colonies were used to transform the expression strain Rosetta-gami2 $\left(\mathrm{DE}_{3}\right)$ pLysS competent cells [40], which were grown in the presence or the antibiotics ampicillin (Sigma, St. Louis, MO, USA) and chloramphenicol (Calbiochem, Billerica, MA, USA), at 50 and $34 \mu \mathrm{g} / \mathrm{mL}$, respectively. Colony PCRs identified positive colonies and three of them that were randomly selected were sequenced in both directions (Instituto de Biotecnología-Unidad de GenómicaINTA Castelar, Castelar, Argentina) using the forward and reverse universal T7 primers.

\subsection{Expression of the Recombinant Lectin Helja in E. coli}

Liquid cultures of positive colonies with an OD at $600 \mathrm{~nm}$ of 0.5 were induced with $0.5 \mathrm{mM}$ of isopropyl- $\beta$-D-thiogalactopyranoside (IPTG, Sigma) at $30{ }^{\circ} \mathrm{C}$ until they reach an OD higher than 1.4. These conditions resulted upon optimization assays performed according to the manufacturer instruction manual testing different IPTG concentration $(0.2-0.5 \mathrm{mM})$, and growth temperature 
$\left(25-37^{\circ} \mathrm{C}\right)$ to produce the higher relative amount of the recombinant protein in the soluble cell fraction. The cells, centrifuged at $10,000 \times g$ for $10 \mathrm{~min}$ at $4{ }^{\circ} \mathrm{C}$, were re-suspended and lysed by sonication in buffer $50 \mathrm{mM} \mathrm{HCl}$-Tris $\mathrm{pH} 8$ and $100 \mathrm{mM} \mathrm{NaCl},(200 \mu \mathrm{L}$ buffer: $1 \mathrm{~mL}$ culture $)$ with 15 bursts of $30 \mathrm{~s}$ (Microson XL, Misonix, Farmingdale, NY, USA). After centrifugation, the supernatant $(\mathrm{SN})$ and the pellet $(\mathrm{PP})$ were recovered for electrophoretic analysis.

\subsection{Purification of the Recombinant Lectin in $\mathrm{Ni}^{2+}$-Sepharose and Mannose-Agarose Matrixes}

Forty $\mathrm{mL}$ of SN, (correspondent to $2000 \mathrm{~mL}$ of cell culture) were loaded on $4 \mathrm{~mL}$ of the $\mathrm{Ni}^{2+}$ affinity matrix cOmplete His-Tag Purification Resin (Roche 05893682001, Pleasanton, CA, USA) previously equilibrated with buffer A ( $50 \mathrm{mM}$ Tris- $\mathrm{HCl} \mathrm{pH} 8$ and $200 \mathrm{mM} \mathrm{NaCl}$ ). They were incubated at $4{ }^{\circ} \mathrm{C}$ for $3 \mathrm{~h}$ with mild agitation before exhaustive washing of the non-retained proteins (NR) with buffer $\mathrm{A}$. The retained fraction $(\mathrm{R})$ was eluted with $15 \mathrm{~mL}$ of buffer A supplemented with $150 \mathrm{mM}$ imidazole at a flow rate of $30 \mathrm{~mL} / \mathrm{h}$. The OD at $280 \mathrm{~nm}$ of the NR and $\mathrm{R}$ fractions was checked. The $\mathrm{R}$ fraction was loaded on $3 \mathrm{~mL}$ of D-mannose-agarose resin (Sigma M6400) equilibrated with buffer B (50 mM Tris- $\mathrm{HCl} \mathrm{pH}$ 7.5, $100 \mathrm{mM} \mathrm{NaCl}$ ). Non-bound proteins were washed before the elution of retained proteins with $12 \mathrm{~mL}$ of buffer B supplemented with $200 \mathrm{mM}$ mannose according to Pinedo et al. [17]. When necessary, fractions were concentrated by acetone precipitation to be analyzed by SDS-PAGE.

\subsection{Digestion of the Recombinant Protein}

The recombinant protein named Trx-rHelja, has three parts: the thioredoxin tag at the N-terminal (Trx) followed by six consecutive histidines, a glutathione tag and the lectin (rHelja) at the $\mathrm{C}$ terminus. All tags can be eliminated by EK digestion. To perform EK digestion, $750 \mu \mathrm{g}$ of the Trx-rHelja were incubated with $0.016 \mathrm{U}$ of recombinant bovine EK (Sigma) for $16 \mathrm{~h}$ at $25^{\circ} \mathrm{C}$ in buffer $50 \mathrm{mM}$ Tris-HCl pH $8.0 ; 2 \mathrm{mM} \mathrm{Ca}_{2} \mathrm{Cl}$ and $1 \% v / v$ Tween 20 (volume $500 \mu \mathrm{L}$ ). The digestion products were evaluated in gels. The rHelja was purified on the $\mathrm{Ni}^{2+}$ affinity matrix as it was described above. Millipore Centricon ${ }^{\circledR}$ Centrifugal Filter Units (cut-off $3 \mathrm{kDa}$ ) (Billerica, MA, USA) were used for protein concentration and buffer exchange. To limit the interaction of the protein with the filter membrane, glycerol in PBS was added till $5 \%$ final concentration.

\subsection{Protein Analysis and Western Blotting}

Gels that were $12 \%$ SDS-PAGE, performed according to Laemmli [41], were stained with Coomassie Brillant Blue R-250. PageRulerTM Prestained Protein Ladder (Fermentas, Life Sciences, Waltham, MA, USA) and Precision Plus Protein ${ }^{\mathrm{TM}}$ Kaleidoscope ${ }^{\mathrm{TM}}$ Prestained Protein Standards (Biorad \#1610375, Hercules, CA, USA) were used as Molecular Mass markers.

The proteins were transferred to $0.45 \mu \mathrm{m}$ nitrocellulose membranes, and incubated in blocking buffer ( $5 \%$ defatted milk in $0.1 \mathrm{M} \mathrm{HCl}$-Tris $\mathrm{pH} 8.0$ ) followed by the addition of anti Helja primary antibodies diluted $1 / 3000$. After overnight incubation, the blot was revealed as described elsewhere [25] using anti-rabbit IgG conjugated with alkaline-phosphatase diluted 1/10,000 (Sigma, St. Louis, MO, USA).

Protein content was quantitated by the bicinchoninic acid method [42] adapted to microplate using bovine serum albumin (Sigma) as the standard.

\subsection{Neuroblastoma Cell Culture}

Human neuroblastoma cell line SH-SY5Y was maintained in complete Dulbecco's Modified Eagle's Medium (DMEM, Sigma) supplemented with $10 \%$ fetal bovine serum (FBS, Internegocios-Argentina, Mercedes, Buenos Aires, Argentina), $100 \mathrm{U} / \mathrm{mL}$ penicillin, $100 \mu \mathrm{g} / \mathrm{mL}$ streptomycin and $0.25 \mu \mathrm{g} / \mathrm{mL}$ amphotericin B (antibiotic-antimycotic solution from Sigma), at $37^{\circ} \mathrm{C}$ in a humidified incubator with $5 \% \mathrm{CO}_{2}$. 


\subsection{Cell Viability Assay}

The viability of the neuroblastoma SH-SY5Y cells treated with Trx-rHelja and rHelja- was determined by the 3-(4,5-dimethylthiazol-2-yl)-2,5-diphenyltetrazolium bromide assay (MTT) according to Mossmann [43] with modifications. Briefly, cells were seeded in 96-well plates at density of $5 \times 10^{4}$ cells/well and incubated for $24 \mathrm{~h}$ in DMEM supplemented with 10\% $(v / v)$ FBS. At that point, they were treated with different micromolar concentrations of Trx-rHelja and rHelja in DMEM- $\%$ FBS. After an additional $24 \mathrm{~h}$, the cultured medium was removed and $100 \mu \mathrm{L}$ of MTT reagent $(1 \mathrm{mg} / \mathrm{mL}$ in DMEM- $1 \%$ FBS) were added to each well and incubated $4 \mathrm{~h}$ at $37^{\circ} \mathrm{C}$. Then, the solution was removed and $100 \mu \mathrm{L}$ of dimethyl sulfoxide was used to dissolve the complex. Absorbance was measured at $570 \mathrm{~nm}$ using a microplate reader ELx800 (Bio-Tek Instruments, Winooski, VT, USA). The percentage of cellular viability was obtained normalizing to the values in the absence of treatment ( $100 \%$ viability). Each treatment was tested in triplicate and the experiment was repeated at least three times. Standard deviation (square root of variance among the three samples in each experiment), one-way ANOVA and Tukey test $(p \leq 0.05)$ analysis were performed using InfoStat software (2014, Agricultural College of the National University of Córdoba, Argentine) (available online: http://www.infostat.com.ar).

\subsection{Microscopic Analysis}

Neuroblastoma SH-SY5Y cells, treated with different concentrations of lectins, were examined by phase contrast microscopy using an Olympus CKX41 inverted microscope with a $10 \times$ lens (Richmond Hill, ON, Canada). Images were acquired with an Olympus Qcolor3 camera associated with QCapture Pro 7 software (QImaging, Surrey, BC, Canada).

\section{Conclusions}

In summary, the sunflower lectin Helja was expressed in Escherichia coli and its identity was verified using immunoanalysis. It was demonstrated that the protein chimera displayed toxicity on human SH-SY5Y neuroblastomas, decreased the viability of these tumor cells by $75 \%$ and simultaneously disturbed the cell morphology. The fact that reports of anti-neuroblastoma lectins are scarce confers relevance to the results, thus rHelja emerges as a promising tool for the development of diagnostic or therapeutic methods for neuroblastoma cells, the most common solid tumors in childhood.

Supplementary Materials: Supplementary materials can be found at www.mdpi.com/1422-0067/18/1/92/s1.

Author Contributions: Marcela Pinedo performed the cloning experiments, wrote the bulk of the manuscript and supervised the project. Melanie Genoula performed the purification and immunoblot assays as well as the figure edition. María Ximena Silveyra performed the assays determining neuroblastoma toxicity. Andre Oliveira Carvalho gave technical support for cloning and wrote part of the manuscript. Mariana Regente contributed with the financial support by grants from CONICET and ANPCyT, and assisted in the arrangement and formatting of the references and proofreading of the manuscript. Marianela Del Río developed tools that improved recovery of the recombinant protein. Júlia Ribeiro Soares assisted in cloning assays. Valdirene Moreira Gomes contributeed with the financial support by grants from Brazilian agencies CNPq, FAPERJ and CAPES/MINCYT (029/2012) and assisted in proofreading the manuscript. Laura De La Canal contributed with analysis and interpretation of data, writing and proofreading the manuscript, and the financial support by grants from CONICET, ANPCYT and UNMDP from Argentina and FAPERJ and CAPES from Brazil. The authors thank the financial support from UNMDP EXA 574/12 and ANPCyT (PICT 736-2014) from Argentina, and the grants from International Cooperation CONICET-FAPERJ and MINCYT-CAPES BR/12/03.

Conflicts of Interest: The authors declare no conflict of interest.

\section{Abbreviations}

CDS coding sequence

Con A concanavalin A

EM extracellular matrix

Helja Helianthus annum jacalin

IPTG isopropyl- $\beta$-D-thiogalactopyranoside 
MTT 3-(4,5-dimethylthiazol-2-yl)-2,5-diphenyltetrazolium bromide

ORF open reading frame

PBS phosphate buffered saline

PCR polymerase chain reaction

ROS reactive oxygen species

\section{References}

1. Sharon, N. Lectins: Past, present and future. Biochem. Soc. Trans. 2008, 36, 1457-1460. [CrossRef] [PubMed]

2. De Schutter, K.; van Damme, E.J.M. Protein-carbohydrate interactions as part of plant defense and animal immunity. Molecules 2015, 20, 9029-9053. [CrossRef] [PubMed]

3. Liu, F.T.; Rabinovich, G.A. Galectins as modulators of tumour progression. Nat. Rev. Cancer 2005, 5, $29-41$. [CrossRef] [PubMed]

4. Pervin, M.; Koyama, Y.; Isemura, M.; Nakamura, Y. Plant lectins in therapeutic and diagnostic cancer research. Int. J. Plant Biol. Res. 2015, 3, 1030-1035.

5. Christiansen, M.N.; Chik, J.; Lee, L.; Anugraham, M.; Abrahams, J.L.; Packer, N.H. Cell surface protein glycosylation in cancer. Proteomics 2014, 14, 525-546. [CrossRef] [PubMed]

6. Gorelik, E.; Galili, U.; Raz, A. On the role of cell surface carbohydrates and their binding proteins (lectins) in tumor metastasis. Cancer Metastasis Rev. 2001, 20, 245-277. [CrossRef] [PubMed]

7. Lavanya, V.; Mohamed Adil, A.A.; Ahmed, N.; Jamal, S. Lectins-the promising cancer therapeutics. Oncobiol. Targets 2014, 1, 12-15.

8. Yau, T.; Dan, X.; Ng, C.C.; Ng, T.B. Lectins with potential for anti-cancer therapy. Molecules 2015, 20, 3791-3810. [CrossRef] [PubMed]

9. Gemeiner, P.; Mislovičová, D.; Tkáč, J.; Švitel, J.; Pätoprstý, V.; Hrabárová, E.; Kogan, G.; Kožár, T. Lectinomics II. A highway to biomedical/clinical diagnostics. Biotechnol. Adv. 2009, 27, 1-15. [CrossRef] [PubMed]

10. Liu, B.; Li, C.; Bian, H.; Min, M.; Chen, L.; Bao, J. Antiproliferative activity and apoptosis-inducing mechanism of Concanavalin A on human melanoma A375 cells. Arch. Biochem. Biophys. 2009, 482, 1-6. [CrossRef] [PubMed]

11. Liu, B.; Zhang, B.; Min, M.W.; Bian, H.J.; Chen, L.F.; Liu, Q.; Bao, J.K. Induction of apoptosis by Polygonatum odoratum lectin and its molecular mechanisms in murine fibrosarcoma L929 cells. Biochim. Biophys. Acta 2009, 1790, 840-844. [CrossRef] [PubMed]

12. Komath, S.S.; Kavitha, M.; Swamy, M.J. Beyond carbohydrate binding: New directions in plant lectin research. Org. Biomol. Chem. 2006, 4, 973-988. [CrossRef] [PubMed]

13. Lam, S.K.; Ng, T.B. Lectins: Production and practical applications. Appl. Microbiol. Biotechnol. 2011, 89, 45-55. [CrossRef] [PubMed]

14. Regente, M.; Taveira, G.B.; Pinedo, M.; Elizalde, M.M.; Ticchi, A.J.; Diz, M.S.; Carvalho, A.O.; de la Canal, L.; Gomes, V.M. A sunflower lectin with antifungal properties and putative medical mycology applications. Curr. Microbiol. 2014, 69, 88-95. [CrossRef] [PubMed]

15. Swanson, M.D.; Winter, H.C.; Goldstein, I.J.; Markovitz, D.M. A lectin isolated from bananas is a potent inhibitor of HIV replication. J. Biol. Chem. 2010, 285, 8645-8655. [CrossRef] [PubMed]

16. Timoshenko, A.V.; Gorudko, I.V.; Gabius, H.J. Lectins from medicinal plants: Bioeffectors with diverse activities. In Recent Advances in Phytochemistry; Jetter, R., Ed.; Springer International Publishing: Cham, Switzerland, 2014; VOlume 44, pp. 43-56.

17. Pinedo, M.; Regente, M.; Elizalde, M.; Quiroga, I.Y.; Pagnussat, L.A.; Jorrín-Novo, J.; Maldonado, A.; de la Canal, L. A non-classically secreted lectin occurs in the apoplast of sunflower seedlings. Protein Pept. Lett. 2012, 19, 270-276. [CrossRef] [PubMed]

18. Regente, M.; Pinedo, M.; Elizalde, M.; de la Canal, L. Apoplastic exosome-like vesicles: A new way of protein secretion in plants? Plant Signal. Behav. 2012, 7, 544-546. [CrossRef] [PubMed]

19. Gurney, J.G.; Ross, J.A.; Wall, D.A.; Bleyer, W.A.; Severson, R.K.; Robison, L.L. Infant cancer in the U.S.: Histology-specific incidence and trends, 1973 to 1992. J. Pediatr. Hematol. Oncol. 1997, 19, 428-432. [CrossRef] [PubMed]

20. Bleckmann, C.; Geyer, H.; Lieberoth, A.; Splittstoesser, F.; Liu, Y.; Feizi, T.; Schachner, M.; Kleene, R.; Reinhold, V.; Geyer, R. O-glycosylation pattern of CD24 from mouse brain. Biol. Chem. 2009, 390, 627-645. [CrossRef] [PubMed] 
21. Poncet, C.; Frances, V.; Gristina, R.; Scheiner, C.; Pellisier, J.F.; Figarella-Branger, D. CD24, a glycosyl phosphatidyl inositol-anchored molecule, is transiently expressed during the development of human central nervous system and is a marker of human neural cell lineage tumors. Acta Neuropathol. 1996, 91, 400-408. [CrossRef] [PubMed]

22. Valentiner, U.; Mühlenhoff, M.; Lehmann, U.; Hildebrant, H.; Schumacher, U. Expression of the neural cell adhesion molecule and polysialic acid in human neuroblastoma cell lines. Int. J. Oncol. 2011, 39, 417-424. [CrossRef] [PubMed]

23. LaVallie, E.R.; DiBlasio, E.A.; Kovacic, S.; Grant, K.L.; Schendel, P.F.; McCoy, J.M.A. Thioredoxin gene fusion expression system that circumvents inclusion body formation in the E. coli cytoplasm. Biotechnology 1993, 11, 187-193. [CrossRef] [PubMed]

24. Pinedo, M.; Orts, F.; Carvalho, A.O.; Regente, M.; Soares, J.R.; Gomes, V.M.; de la Canal, L. Molecular characterization of Helja, an extracellular jacalin-related protein from Helianthus annuus: Insights into the relationship of this protein with unconventionally secreted lectins. J. Plant Physiol. 2015, 183, 144-153. [CrossRef] [PubMed]

25. Li, Y.; Liao, X.; Chen, G.; Yap, Y.; Zhang, X. Cloning, Expression and Purification of Microcystis viridis Lectin in Escherichia coli. Mol. Biotechnol. 2011, 47, 105-110. [CrossRef] [PubMed]

26. Haraguchi, T.; Nomura, K.; Yagi, F. Cloning and expression of a mannose-binding Jacalin-Related lectin from leaves of Japanese Cycad (Cycas revoluta Thunb.). Biosci. Biotechnol. Biochem. 2006, 70, 2222-2229. [CrossRef] [PubMed]

27. Oliveira, C.; Costa, S.; Teixeira, J.A.; Domingues, L. cDNA cloning and functional expression of the alpha-D-galactose-binding lectin frutalin in Escherichia coli. Mol. Biotechnol. 2009, 43, 212-220. [CrossRef] [PubMed]

28. Sahasrabuddhe, A.A.; Gaikwad, S.M.; Krishnasastry, M.V.; Khan, M.I. Studies on recombinant single chain Jacalin lectin reveal reduced affinity for saccharides despite normal folding like native Jacalin. Protein Sci. 2004, 13, 3264-3273. [CrossRef] [PubMed]

29. Oliveira, C.; Nicolau, A.; Teixeira, J.A.; Domingues, L. Cytotoxic effects of native and recombinant frutalin, a plant galactose-binding lectin, on HeLa cervical cancer cells. J. Biomed. Biotechnol. 2011, 2011, 568932. [CrossRef] [PubMed]

30. Cheung, A.H.; Wong, J.H.; Ng, T.B. Musa acuminata (Del Monte banana) lectin is a fructose-binding lectin with cytokine-inducing activity. Phytomedicine 2009, 16, 594-600. [CrossRef] [PubMed]

31. Vetri, V.; Carrotta, R.; Picone, P.; di Carlo, M.; Militello, V. Concanavalin A aggregation and toxicity on cell cultures. Biochim. Biophys. Acta 2010, 1804, 173-183. [CrossRef] [PubMed]

32. Schmidt, M.L.; Kuzmanoff, K.L.; Ling-Indeck, L.; Pezzuto, J.M. Betulinic acid induces apoptosis in human neuroblastoma cell lines. Eur. J. Cancer 1997, 33, 2007-2010. [CrossRef]

33. Gu, J.; Isaji, T.; Xu, Q.; Kariya, Y.; Gu, W.; Fukuda, T.; Du, Y. Potential roles of N-glycosylation in cell adhesion. Glycoconj. J. 2012, 29, 599-607. [CrossRef] [PubMed]

34. Notter, M.F.I.; Leary, J.F. Surface glycoproteins of differentiating neuroblastoma cells analyzed by lectin binding and flow cytometry. Cytometry 1987, 5, 518-525. [CrossRef] [PubMed]

35. Kim, M.; Rao, M.V.; Tweardy, D.J.; Prakash, M.; Galili, U.; Gorelik, E. Lectin-induced apoptosis of tumour cells. Glycobiology 1993, 3, 447-453. [CrossRef] [PubMed]

36. Kim, M.S.; So, H.S.; Lee, K.M.; Park, J.S.; Lee, J.H.; Moon, S.K.; Ryu, D.G.; Chung, S.Y.; Jung, B.H.; Kim, Y.K.; et al. Activation of caspases cascades in Korean mistetloe (Viscum album varcoloratum) lectin-II-induced apoptosis of human myeloleukemic U937 cells. Gen. Pharmacol. 2000, 34, 349-355. [CrossRef]

37. Suen, Y.K.; Fung, K.P.; Choy, Y.M.; Lee, C.Y.; Chan, C.W.; Kong, S.K. Concanavalin A induced apoptosis in murine macrophage PU5-1.8 cells through clustering of mitochondria and release of cytochrome c. Apoptosis 2000, 5, 369-737. [CrossRef] [PubMed]

38. Lam, S.K.; Ng, T.B. First report of a haemagglutinin-induced apoptotic pathway in breast cancer cells. Biosci. Rep. 2010, 30, 307-317. [CrossRef] [PubMed]

39. Faheina-Martins, G.V.; da Silveira, A.L.; Cavalcanti, B.C.; Ramos, M.V.; Moraes, M.O.; Pessoa, C.; Araújo, D.A. Antiproliferative effects of lectins from Canavalia ensiformis and Canavalia brasiliensis in human leukemia cell lines. Toxicol. In Vitro 2012, 26, 1161-1169. [CrossRef] [PubMed] 
40. Inoue, H.; Nojima, H.; Okayama, H. High efficiency transformation of Escherichia coli with plasmids. Gene 1990, 96, 23-28. [CrossRef]

41. Laemmli, U.K. Cleavage of structural proteins during the assambly of the head of bacteriophage T4. Nature 1970, 227, 680-685. [CrossRef] [PubMed]

42. Smith, P.K.; Krohn, R.J.; Hermanson, G.T.; Mallia, A.K.; Gartner, F.H.; Provenzano, M.D.; Fujimoto, E.K.; Olson, B.J.; Klenk, D.C. Measurement of protein using bicinchoninic acid. Anal. Biochem. 1985, 50, 76-85. [CrossRef]

43. Mossmann, T. Rapid colorimetric assay for cellular growth and survival: Application to proliferation and cytotoxicity assays. J. Immunol. Meth. 1983, 65, 55-63. [CrossRef]

(C) 2017 by the authors; licensee MDPI, Basel, Switzerland. This article is an open access article distributed under the terms and conditions of the Creative Commons Attribution (CC-BY) license (http://creativecommons.org/licenses/by/4.0/). 